\title{
5.6 Periurban luxembourg. Definition, Positioning and Discursive Construction of Suburban Spaces at the Border between City and Countryside
}

\author{
Markus Hesse
}

“[...] The in-between city represents places that are 'not quite traditional city and not quite traditional suburban' (Young and Keil, 2010). They are forgotten geographies, where many people live and where [...] the dialectical treatment of urban versus suburban neglects the many shades of urban places that require our planning and policy attention" (Kirby/ Modarres 2010: 67).

The expansion of urban settlements beyond the borders of the (nucleus) city into previously non-urban spaces is a central feature of spatial development of the pre- and postwar period in the overwhelming majority of western industrialized nations, in Europe as much as in North America and Australia (see Harris/Larkham 1999). Point of departure of this process are the migrations from city to hinterland of households or enterprises, particularly industry, later also of commerce as well as recreational facilities. Ever since the onset of industrialization, more or less continuous population and employment growth has been over lengthy periods the normal mode of urban development. This has produced polycentric urban regions that display very diverse structures (see Kloosterman/Musterd 2001; Parr 2004).

Scientific analysis in geography and spatial research has traditionally assigned the term of suburbanization to the expansion of the city beyond its borders (see Pratt 1994; Harris 2006); in francophone countries, this is also referred to as périurbanisation (see Paluch 1997; Piorr et al. 2011). This term also includes spaces that are further removed from the centre, spaces whose development is defined in English-speaking countries with the term of counterurbanization (see Champion 1989; Mitchell 2004). Counterurbanization refers to the growth of nonmetropolitan locations, with the perspective here being expanded to the category of the rural space - those sparsely populated spaces, in earlier times marked by agriculture and forestry, which today still comprise substantial areas of Europe's large countries.

The expansion of the cities and the concomitant urbanization of society had two important consequences: on the one hand, it created transitory spaces in the in-between area between city and countryside, with, compared to the city, low density of development, a higher percentage of free spaces and fewer places of employment and recreational facilities - but with clearly more intensive land uses than in rural regions. These fringe spaces were, in the beginning, based in a high degree on the division of labor between city and hinterland, partly also peripheral rural spaces. Today this hinterland has in many cases emancipated itself from the core city, has become more urban, a part of the polycentric urban region. On the other hand, the emergence of transitory spaces has created a situation where it has 
become (almost) impossible to make meaningful and clear distinctions between city, countryside and in-between spaces, particularly in the agglomerations. The various spatial types are parts of a continuum that are increasingly merging into each other, particularly in the fringe areas of the large metropolitan areas. Until now, however, there has been a lack of appropriate conceptualizations for describing these spatial types (see Harris 2010), and over a long period of time they did not feature very prominently as a subject of spatial analyses and spatial planning. In the course of a tendency towards urbanization of modern society perceived as 'planetary', the boundary between city and countryside is even regarded by some observers as entirely obsolete (see Schmid/Brenner 2011). This dictum is explained with the worldwide growing urban population; since 2007, it is assumed that - for the first time in history - there are more people living in cities than in the countryside. This thesis of a universal tendency towards urbanization of society follows the assumption that space is produced socially, but that spatial differences between city and countryside no longer have any real social relevance.

The emergence of hybrid spatial categories or the tendency towards dissolution of clear differentiations between city and countryside are signals of more complex conditions and progressions of spatial development. These include, besides urbanization and the growth of urban spaces, significant social and spatial-temporal differentiations of, for instance, mobility, migration and internationalization. The same applies to the incorporation of regions into larger functional systems, e.g. through cultural and economic globalization. This development has also contributed to territory, city and region no longer being perceived as territorially constituted and clearly defined but rather as relational: as an object of a complex system of relations that is read by very diverse actors along 'variable geometries' (i.e. flexible spatial understandings) and is situated on different levels of scale (local, regional, global) (see Raco 2006).

\subsubsection{Spatial Categories and Attributions: The Constitution of Space in City, Countryside and the 'In-between'}

"Scholars researching suburbia in the framework of different disciplines still have no easy overview of what the different areas of their subject have in common" (Vaughan et al. 2009: 485).

When social change can no longer be grasped with the traditional inventory of scientific terms, epistemologies and methods, it causes a productive irritation. This basically also applies to spatial development. With regard to this subject, one can draw three possible conclusions in reaction to this situation: the first is to search for a fundamentally new paradigm - in this case, the conceptualization of the 'postmodern' city as a rupture with the 'old' city's logic of development; a second option would be to retain what has been passed down, what has proven its worth also under such marginal conditions that suppose transformation and

E-Book von Christian Wille, christian.wille@uni.lu 27.01.2016 17:18

Copyright 2016, transcript Verlag, Bielefeld 
change - this would here correspond to assuming the universally valid return or renaissance of the city. The third possibility would be to adopt a different conceptual perspective. This is the logic also followed by the present paper. It implies that the research subject is no longer assumed as given, but is understood as a case of individual, subjective constructions.

Such a perspective views space as a result of social agency, as socially constituted and socially constructed (see sections 2.2 and 5.1). This perspective is also well justified with regard to the subject discussed here: the question of what can be called 'urban', 'suburban' or 'rural' is no longer determined via classical parameters of spatial science (such as population potential and density, spatial location, commuter relations to the nearest centre). Instead, 'city' and 'countryside' are actively created, produced. The accompanying attributions detach themselves from scientific categorizations and positings - which themselves of course also constitute constructions - and are increasingly performed by the subjects themselves. Attribution of meaning ensues both in the professional discourse, i.e. through scientists, politicians and planners as well as through the population itself. Here various factors come into play: space-related identities and identifications, demarcations, policies and ideological framing as well as subjectivations and subjectifications, i.e. individual perceptions and positings, but also the concomitant practices.

This is confirmed when we consider the contradictory perceptions and evaluations of what constitutes urban and rural spaces (and lifestyles) or what differentiates them. Spaces that were previously perceived as rural are no longer necessarily peripheral but also appear as highly industrialized, are subject to social integration and social modernization (see Woods 2007); at the same time, some cities ruralize, in particular those that have lost considerable numbers of inhabitants due to deindustrialization or transformation. Interim usages, urban gardening and agricultural subsistence on fallow soil are playing a more prominent role and at least in part are shaping a new perception of the city. This blending of the traditional images of city and countryside corresponds to a coincidence of competing ideal images of both spatial categories: the image of the renaissance of the city in which many people live, work, spend their free time, again is found alongside new urban poverty and exclusion. And in contrast to the reality of many successful agro-industrial and logistic production spaces that have established themselves in rural-peripheral regions, for some time now there has been a remarkable orientation of the urban mainstream society towards the rural. This is also reflected in the high demand for lifestyle magazines that offer country life, country culture and countryside nostalgia as a communicative staging.

The perception of sub- and periurban spaces is also very contradictory: the city fringe has always been both privatopia and dystopia - i.e. private space of retreat and yearning on the one hand, which offered the perspective to maximize the respective advantages of city and countryside and avoid their disadvantages. And on the other hand, the suburban space was a projection area of a sweeping critique 
of urban growth (see Nicolaides 2006; Vicenzotti 2011), chiefly from the ranks of architects and urban planners, but also from the core cities themselves. This critique was aimed at the urbanization of free space, the fiscal depletion of the core cities through the haemorrhage of tax-paying households as well as the creation of commuter migrations. But it was voiced primarily from the perspective of the core city and to a lesser degree from the angle of the peripheral regions themselves (see Hesse 2010). ${ }^{110}$ The narrative of the dissolution of the city was for a long time very impactful if not hegemonial.

The constructivist perspective on space is guided by an awareness for the particular significance of boundaries. Boundaries are constitutive for spaces and thus also for the traditional understanding of the suburban or periurban. It is administrative boundaries and those drawn by settlement structures that create the fact of the margin in the first place: in purely statistical terms, it is frequently only the crossing of the municipal boundary that transforms the migration from the centre to the periphery into a matter of suburbanization. Furthermore, suburban spaces are found on both sides, inside and outside, of the boundary of the core city. Here, the most distinctive demarcation of boundaries ensued discursively, referring to the heated controversies within the respective policy departments about suburbia (see above) that formed a marked contrast to its residents' high appreciation for this spatial category. The core city was assessed positively, while the areas beyond the city limits were given a negative evaluation.

Finally, connections also emerge to 'identity' in a spatial context. Here we differentiate between the attributed identity of a region or a space and the identification of individuals with particular spaces or places (see Paasi 2002 and 2003; Weichhart 1999). Regarding the question of space-related identity, we subscribe to the view of Paasi (2003: 477):

"Regional identity has been recognized as a key element in the making of regions as social/ political spaces, but it is difficult to elucidate what this identity consists of and how it affects collective action/politics [...]. The crucial question is how political passions are regionalized, and here institutions constitutive of region-building (economy, governance, language, media, literature) and inherent power relations are significant."

Against this background, the aim of this paper is to explore the constitution and the construction of segmented space at a remove from the big centres. The focus will be on the perspective of the inhabitants of these areas. What interests us is how the inhabitants of the periphery associate their locations and in which way, if any, space-related identity is shaped. It continues to remain unclear how the

110 | And it has remained unclear who precisely was the addressee of this critique: the subjects that chose this location type; economic actors who found particularly favourable conditions of exploitation here; or the planning and regulative policies that have created the necessary incentives for the respective social practices.

E-Book von Christian wille, christian.wille@uni.lu 27.01.2016 17:18

Copyright 2016, transcript Verlag, Bielefeld 
inhabitants of suburbia, the in-between city, the suburban space actually call the place where they live, which images they associate with it, and in how far this space is perceived as 'home'. In that respect, processes of demarcation of boundaries and identity-building are equally relevant. This particular way of looking at space also makes it possible to question conventional positings and hegemonial discourses and to open and pluralize the perspective. We have chosen the Grand Duchy of Luxembourg and the Greater Region, i.e. including the neighbouring regions Wallonia, Lorraine, Rhineland-Palatinate and Saarland as an example for examining this complex of questions (see University of Luxembourg, IDENT2 $2012 / 2013$ - quantitative and qualitative survey). It is an attempt to understand the constitution of sub- and periurban spaces as a product of a specific subjectivation. Building on this, we will discuss a number of implications for further research.

\subsubsection{The Suburban and Periurban Regional Scenario in Luxembourg and in the Border Region}

Compared to other European countries, the Grand Duchy of Luxembourg, one of the smallest member states of the European Union, has seen an above-average favourable demographic development and an extremely successful economic transformation. This developmental path is moreover characterized by two particular features compared to urban development in other contexts: it took place in a very short period of time and in a relatively small territory, which at the end of 2012/beginning of 2013 comprised around 537,000 inhabitants and around 380,000 resident employees on an area of $2,586 \mathrm{~km}^{2}$ (see STATEC 2013: 9). Recent spatial development of Luxembourg has been very disparate: a few densely populated areas contrast with a generally more segmented region. The country's north is traditionally regarded as rural. The great majority of the country's 106 municipalities have a population of less than 10,000. In the past, the highest development pressure, measured in absolute figures, was sustained by the metropolitan area, while many smaller municipalities show the highest relative gains in growth.

The country's housing and real estate markets are extremely tense (see Becker/Hesse 2010); even compared to the substantially higher level of income, rents and real estate prices are generally double to those in comparable locations in Germany, Belgium or France. After a first wave of suburbanization in the 1970s and 1980 s, these problems created an increased cross-border residential mobility out of Luxembourg. It has been directed primarily to the periurban rural area near the border of Rhineland-Palatinate, Wallonia and Lorraine (see section 5.8). Near the national border, the settlement area dynamics are currently much more pronounced than in the centres. This is not only true for the transformation of erstwhile villages and smaller towns to residential locations of the urban commuter population, but, particularly in Luxembourg, also for the office locations interspersed in the more rural parts of the country, which constitute 
largely unintegrated workplace concentrations. The spatial imbalances that come with massive daily commuter traffic and continuing problems in the provision of housing are currently considered the major problem for regional planning.

If the combination of relatively small territory size, large-scale interlacement and very dynamic growth of economy and population in the past two decades in itself already creates very specific constraints for spatial development, then this applies even more to the ongoing internationalization of the country. This is already evident in the country-wide very high percentage of non-Luxembourg nationals of $44 \%$, reflecting the various waves of immigration in the country's recent past. But in the small municipalities it encounters a very specific regional scenario: in municipalities of not more than approx. 8,000 inhabitants, such as Walferdange in the northern periphery of the capital, or Mersch in the country's centre, the proportion of foreigners is as high as $30 \%$ or more representing around 90 to 100 or more different nationalities (see the websites of the communes of Mersch and Walferdange). Especially for small municipalities, this is extraordinarily high and poses a particular challenge. This diversity is less marked in the municipalities near the border which instead have a more balanced mixture of nationals from the respective bordering countries.

\subsubsection{Empirical Glimpses into Sub- and Periurban Constellations}

"It's suburban. You got a forest and, I mean, in Luxembourg nothing is really urban unless you live right in the middle of Grand-rue." (male, 48, British Luxembourger, Luxembourg).

This section will provide a few selected empirical glimpses into the constitution of sub- and periurban space in Luxembourg and in the border region. In two rounds of empirical research, we examined the interpretations and attributions of meaning with respect to people's place of residence. First we formulated, as part of the quantitative survey, a short set of questions relating to grading the place of residence according to the degree of urbanization. We asked the interviewees how they rated their residential location: as urban, rural or sub-/periurban. In addition, we conducted semi-standardized interviews with 23 selected respondents who had participated in the quantitative survey and had given their ratings and were willing to discuss the reasons for their choice.

\section{Perceptions of the 'In-Between'}

Fig. 1 and 2 show a compilation of the results arrived at in the standardized survey. On the one hand, they refer to the entire area covered by the survey as well as to those areas of the respective countries' territory that constitute a part of the Greater Region, and on the other, to the different regions of Luxembourg. We see here a relatively high degree of correspondence with the classifications suggested by these particular areas on the basis of the features of their space and settlement structure or which have been put forward by the respective spatial planning 
authorities or the European Spatial Planning Observation Network (ESPON): “The Greater Region shows a clear functional, demographic, and morphological polycentricity that is the basis for the overall functioning of the region" (ESPON/ UL 2010). With the exception of Lorraine, most parts of the entire area covered by the survey are rated as having a predominantly rural or sub/-periurban structure; in the Saarland and the Rhineland-Palatinate, part of the survey area ratings of suburban and rural are more or less evenly distributed (see Fig. 1). Among the different areas within Luxembourg, the contrasts are even stronger. Here the area of the capital stands out as urban with $6_{1} \%$ of the ratings. What is remarkable here is the low percentage of ratings given to this category for the rest of the centre. As expected, the south is rated both as sub-/periurban as well as rural; and for Luxembourg's northern and eastern regions the category 'rural' is - also unsurprisingly - the predomiant one (see Fig. 2).

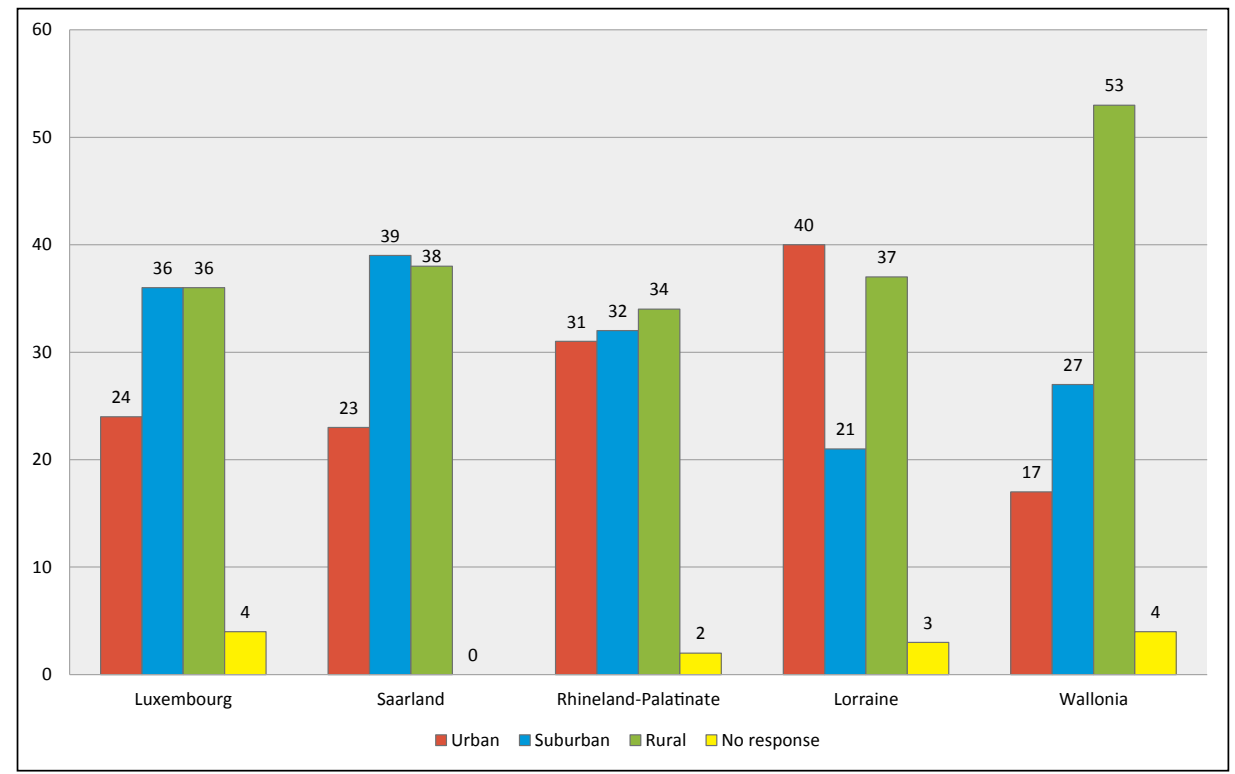

Figure 1: How would you describe your lifestyle in this location? Entire survey area in percent (University of Luxembourg, IDENT2 2012/2013 - quantitative survey) 


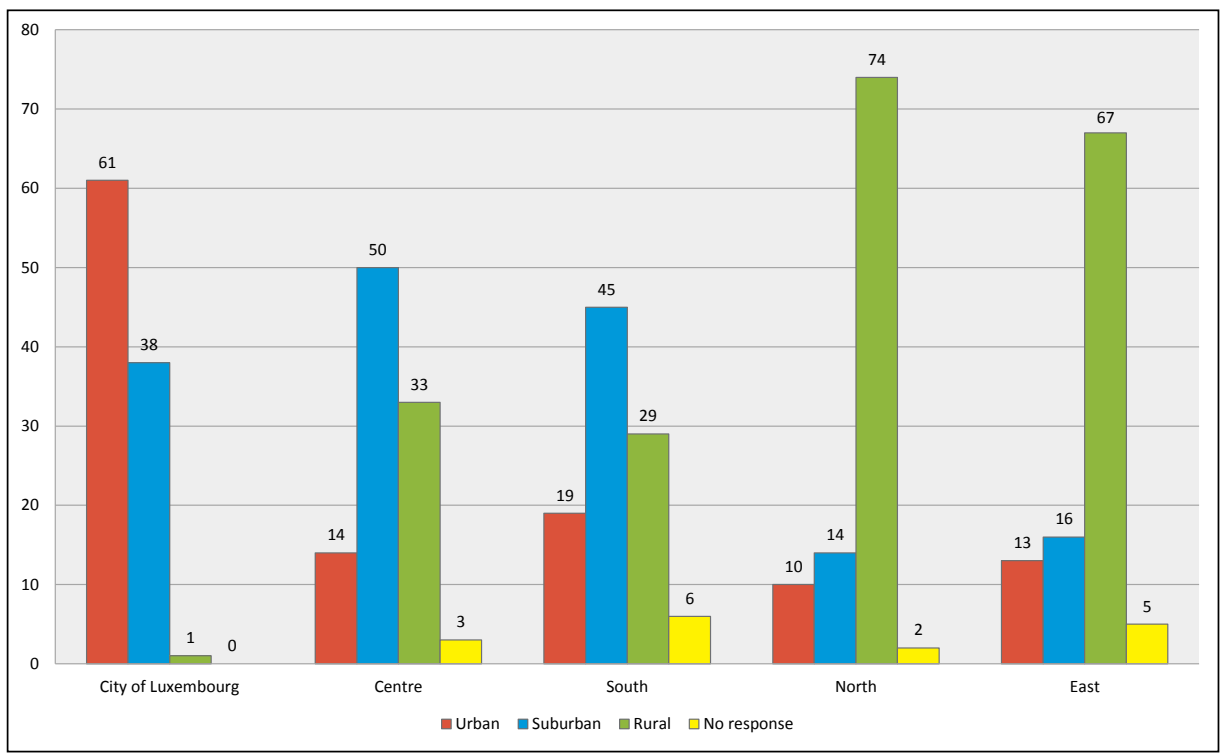

Figure 2: How would you describe your lifestyle in this location? Luxembourg residential population in percent (University of Luxembourg, IDENT2 2012/2013 quantitative survey)

By comparison, responses from the semi-standardized survey are clearly less consistent. The selection of the in this case 23 respondents followed the selfassessment of the participants who had given their rating of their place of residence for the standardized survey and were willing to discuss the reasons for their choice in detailed personal interviews. These covered the following question: Does the place where you live have a clear boundary? Where does it begin, where does it end? How do you describe the place where you live to acquaintances or strangers? Why do you qualify your home town as urban, suburban, rural? Would you say that you identify with the place where you live? If so, why? If not, why not?

At first, a majority of the interviewees reacted to these questions with puzzlement. Apart from a few exceptions (see below) people are not accustomed to using the classical terminologies of space-related planning and research in their everyday lives. Only a minority of interviewees came up with precise terms on their own accord: instead, the interviewees offered detailed narratives with which they situated themselves in or also identified themselves with their place of residence.

"Where does it begin? At the border, where you can immediately..., but... OK, the whole of Athus also belongs to it, I mean, it's... nowadays it all connects what now..."111 (female, 31, Luxembourgish, Wallonia).

111 | Eigene Übersetzung von: "Wou fänkt en un? Vun der Grenz, wou een direkt zwar... Okay, ganz Athus gehéiert dozou, ech mengen, et ass jo... alles hänkt zesummen, wat elo..." 
The transcripts of the conversations document numerous queries on the part of the interviewees attempting to understand the research interest of the survey. This response can have two different reasons: on the one hand, this clearly confirms the marked discrepancy between the use of corresponding terminologies by experts and by residents (this problem was already broadly discussed during the coordination of the interview guideline). Interviewers were obliged to provide explicit assistance and explanations for the interviewees to be able to position themselves. On the other hand, this probably also has to do with the fact that in particular in the urbanized parts of the survey area - i.e. beyond the rural areas -, clear boundaries between city and countryside are more the exception than the rule. This is reflected in the vagueness of attributions made by the residents of those areas.

Next, the evaluation of the empirical findings will focus on the following two question items: How is the place of residence referred to? Are there indications for a space-related identification and how is it reflected? Interviewees living in an urban centre or in a village (centre) gave an unambiguous answer to the question about the place of residence. In the other cases, the terminology is inconsistent and varied, due to the already mentioned problem of demarcating clear boundaries. On Luxembourg territory and in the German-speaking border region, the terms "Stadtrand" and "Vorstadt" or "Vorort" (lux. Viruert) are used; an English speaking interviewee was the only one to use the term 'suburban'. The francophone interviewees characterize their place of residence in this case as "entre les deux", i.e. in the in-between between city and countryside, which offers certain advantages ("un peu des deux côtés - on a des avantages”). It is only French speaking people that use the term zone périurbaine. "Vorstadt" refers as a rule to the nearest centre. In rural Germany, territorial reforms have created the effect that for the inhabitants of smaller neighbourhoods it is not the administrative seat of the municipality that is the chief place of reference but the place of residence.

Here one needs to take into account the particular features of the urban system in Luxembourg whose 106 municipalities consist in large part of small municipalities with less than 10,000 inhabitants. Often evaluations oscillate between the formal municipal charter and the actual significance of the municipality; frequently independent small municipalities are attributed more importance for reasons of political symbolism than they de facto have. Occasionally, the label of the rural is also used for settlement nuclei that have, according to the same interviewee's information, around 3,500 inhabitants, therefore, by the standards of the region, exhibiting more of an urban character, i.e. being attributed specifically urban features.

\section{Evaluations of the 'In-between'}

This scale connected with good accessibility by car (only public transport is rated as unsastisfactory) has in general a positive effect on the evaluation of the places of residence: "But I'm, like, two kilometres from the city. So it's not countryside, either? No, it's just perfect!" (female, 53, Finnish, Luxembourg). Interviewees give positive ratings throughout to the location of their place of residence and the corresponding 
local and regional surroundings. This is partly due to the already mentioned scale of the spatial structure, in particular to the fact that the survey area by and large, barring a few exceptions (areas in Rhineland-Palatinate relatively remote from the border), does not consist of peripheral rural areas, and that also many of the locations classified as rural lie in the catchment area of the urban centres and are easily accessible. In this way, the widely scattered in-between spaces permit a high degree of benefit maximization in the interface of settings that lean more to the urban and more to the rural, which belongs to the classic motivations for choosing a place of residence in sub- and periurban areas (see Mitchell 2004; McCarthy 2008).

"I would like to move, but the problem is that I don't want to move away from here. I don't really like my house, but the place is practical, the neighbourhood. We're not cramped, everyone has their garden, that's why I don't know. If I move, I would need to find something here"112 (female, 33, French, Lorraine).

The interviewees' direct ratings of the quality of their location are positive throughout ("I have here everything I need"; "very nice, small place, very calm, pleasant"113; "only advantages.") The empirical material yields only limited indications for space-related appropriations. Corresponding points of reference are in this case clearly linked to social contexts: the determining factors here are family, neighbours, leisure activities:

"And you feel a sense of belonging to that... place, commune?" -"Yes, in the fact that the kids went to school there and that through that I know a lot of the parents. I know a lot of the activities so I get invited to a lot of things where there will be a lot of people from Strassen. My kids used to play for the football team and things. So, yes, you get to know the people. But no, I would never say I am a 'Strassener'. I am more of a... I'm very European in the way I position myself. I have an English passport but, you know, I speak languages. I don't attach myself to a... place" (male, 48, British Luxembourger, Luxembourg).

The ratings and assessments referring to space-related appropriation processes are made in the very specific context of Luxembourg which is marked by a basic contradiction between more segmented spatial configurations and constellations, on the one hand, and an apparently great diversity of social practices, attitudes and assessments, on the other. This situation reflects the critically examined role that the category 'space' plays for subjectivation processes in the context of constructivist approaches to research.

112 | Eigene Übersetzung von: “Moi j'aimerais bien déménager, mais le problème, c'est que je ne veux pas partir d'ici. Ma maison ne me plaît pas forcément, mais c'est l'endroit qui est pratique; le voisinage, on n'est pas trop collés les uns sur les autres, on a chacun un jardin, donc je ne sais pas. Si je déménage, il faudrait que je trouve ici, en fait."

113 | Eigene Übersetzung von: "Très sympathique petite localité, très calme, plaisible."

E-Book von Christian Wille, christian.wille@uni.lu 27.01.2016 17:18

Copyright 2016, transcript Verlag, Bielefeld 


\subsubsection{Conclusion}

It was the aim of this case study to examine how the category of sub- and periurban space in Luxembourg and in the border region is specifically constituted by its inhabitants. The subjective assessments that emerge in the spatial classifications of place of residence correspond at first glance to the 'objective' features with which these locations are characterized in the professional discourse. At second glance, however, these categorizations are relatively scattered, very segmented and greatly dependent on the local context. As far as statements are made about residential satisfaction, these are all positive, consistent with the research on choice of residential location and motivations (see Beckmann et al. 2006). Close ties are confirmed with respect to the social context. But these are not necessarily explainable in the spatial context. So the question whether there is something like a space-related identity or identification on the basis of this evaluation has to remain unanswered. We should here point out the special importance of infrastructures: it is only thanks to the high degree of motorization and the good spatial development that the dispersed life in the sub- and periurban space has become feasible and attractive.

This picture seems to confirm the afore-mentioned tendency towards dissolution of sharp contours of 'urban' and 'rural' spaces also for the area examined here. This yields at least two points for further discussion: first, one would need to clarify what the concomitant hybridization of spatial contexts actually signifies. Secondly, we have to ask ourselves how meaningful are spatial categorizations at all, in particular when we are dealing with such complex questions as 'identity': "Geographical spaces are now overlapped by many and varied social and cultural ideas, requiring a reconceptualisation of space as a socially produced set of manifolds [...], better recognised as territories of becoming able to produce new potentials rather than as fixed territories of identity" (Cloke 2011: 568 ).

\subsection{Remembering the Second World War in LuXembourg AND the Border Regions OF ITS Three NeIghbOURS}

\section{Eva Maria Klos and Benno Sönke Schulz}

In 2006, the cultural studies scholar Aleida Assmann stated with regard to the Second World War and the Germans: "We live in the shadow of a past that in manifold ways continues to make itself felt in the present and haunt later generations with emotional dissonance and moral dilemmas"114 (Assmann 2006: 159). The Nazi period is still present in German and European everyday life - be it

114 | Personal translation of: "Wir leben im Schatten einer Vergangenheit, die in vielfältiger Form in die Gegenwart weiter hineinwirkt und die Nachgeborenen mit emotionaler Dissonanz und moralischem Dilemma heimsucht." 


\subsection{References}

Althusser, Louis (1971 [1970]): “Ideology and Ideological State Apparatuses", in: Lenin and Philosophy and Other Essays (trans. Ben Brewster), Monthly Review Press, 121-176.

Andrikopoulou-Strack, Jeanne-Nora (1986): Grabbauten des 1. Jahrhunderts n. Chr. im Rheingebiet, Köln: Rheinland-Verlag.

Assmann, Aleida (2006): Der lange Schatten der Vergangenheit. Erinnerungskultur und Geschichtspolitik, München: C.H. Beck.

Assmann, Aleida (2008): “Transformations between History and Memory”, in: Social Research 75, 49-72.

Baltes-Löhr, Christel (2000): “Migration als Subversion des Raumes”, in: Renate von Bardeleben (ed.), Frauen in Kultur und Gesellschaft. Ausgewählte Beiträge der 2. Fachtagung Frauen-/Gender-Forschung in Rheinland-Pfalz, Tübingen: Stauffenburg Verlag, 513-524.

Baltes-Löhr, Christel (2003): “Grenzverschiebungen. Theoriekonzepte zum Begriff 'Grenze”, in: Thomas Geisen/Allen Karchen (eds.), Grenze: Sozial - Politisch - Kulturell. Ambivalenzen in den Prozessen der Entstehung und Veränderung von Grenzen, Frankfurt a.M./London: IKO-Verlag für Interkulturelle Kommunikation, 82-98.

Baltes-Löhr, Christel (2006): Migration und Identität. Portugiesische Frauen in Luxemburg, Frankfurt a.M./London: IKO-Verlag für Interkulturelle Kommunikation.

Baltes-Löhr, Christel (2014): “Geschlechterpluralitäten”, in: Heinz Sieburg (ed.), Geschlecht in Literatur und Geschichte. Bilder - Identitäten - Konstruktionen, Bielefeld: transcript.

Bauman, Zygmunt (2000): Liquid Modernity, Cambridge: Polity Press.

Becker, Tom/Hesse, Markus (2010): “Internationalisierung und Steuerung internationaler Wohnungsmärkte - das Beispiel Luxemburg”, in: Informationen zur Raumentwicklung 5/6, 403-415.

Becker, Ruth (2008): “Angsträume oder Frauenräume? Gedanken über den Zugang von Frauen zum öffentlichen Raum”, in: Feministisches Kollektiv (ed.), Street Harassment. Machtprozesse und Raumproduktion, Wien: Mandelbaum Verlag, 56-74.

Beckmann, Klaus/Hesse, Markus/Holz-Rau, Christian/Hunecke, Marcel (eds.) (2006): Stadtleben. Wohnen, Mobilität und Lebensstil, Wiesbaden: Verlag für Sozialwissenschaften.

Benedikter, Roland (2011): “Subjekt”, in: Helmut Reinalter/Peter J. Brenner (eds.), Lexikon der Geisteswissenschaften, Wien/Köln/Weimar: Böhlau Verlag.

Benjamin, Walter (1968 [1955]) “The Work of Art in the Age of Mechanical Reproduction" (trans. Harry Zohn), in: Hannah Arendt (ed.), Illuminations, New York: Harcourt, Brace \& World. 
Berger, Maxi (2013): “Autonome Subjekte und der Vorrang des Objekts. Überlegungen zu einer Implikation von Praxistheorien”, in: Thomas Alkemeyer/ Gunilla Budde/Dagmar Freist (eds.), Selbstbildungen. Soziale und kulturelle Praktiken der Subjektivierung, Bielefeld: transcript, 313-328.

Bourdieu, Pierre (1986): “The forms of capital”, in: J. Richardson (ed.) Handbook of Theory and Research for the Sociology of Education, New York: Greenwood, 241-258.

Brosius, Jacques/Carpentier, Samuel (2010): “Grenzüberschreitende Wohnmobilität von in Luxemburg ansässigen Erwerbstätigen: Quantifizierung und Charakterisierung des Phänomens", in: Samuel Carpentier (ed.), Die grenzüberschreitende Wohnmobilität zwischen Luxemburg und seinen Nachbarregionen, Luxemburg: Editions Saint-Paul, 15-36.

Brunner, Karl-Michael (2003): “Konsumprozesse im Ernährungsfeld: Chancen für Nachhaltigkeit?”, in: Internationaler Arbeitskreis für Kulturforschung des Essens, Mitteilungen 10, 22-29.

Brunner, Karl-Michael (2007): “Ernährungspraktiken und nachhaltige Entwicklung - eine Einführung”, in: Karl-Michael Brunner/Sonja Geyer/Marie Jelenko /Walpurga Weiss/Florentina Astleithner (eds.), Ernährungsalltag im Wandel. Chancen für Nachhaltigkeit, Wien/New York: Springer, 1-38.

Bucholtz, Mary/Hall, Kira (2005): “Language and Identity”, in: Alessandro Duranti (ed.): A Companion to Linguistic Anthropology. Reprint (= Blackwell Companions to Anthropology, vol. 1), Malden: Blackwell, 369-394.

Bührmann, Andrea/Schneider, Werner (2007): “Mehr als nur diskursive Praxis? - Konzeptionelle Grundlagen und methodische Aspekte der Dispositivanalyse”, in: Forum Qualitative Sozialforschung/Forum Qualitative Social Research 8, Art. 28, http://www.qualitative-research.net/index.php/fqs/article/ view/237/525, accessed 23.12.2013.

Bührmann, Andrea/Schneider, Werner (2008): Vom Diskurs zum Dispositiv. Eine Einführung in die Dispositivanalyse, Bielefeld: transcript, 176.

Bürkner, Hans-Joachim (2011): “Zwischen Naturalisierung, Identitätspolitik und Bordering - Theoretische Ansatzpunkte für die Analyse von Identitäten in Grenzräumen”, in: Wilfried Heller (ed.), Identitäten und Imaginationen der Bevölkerung in Grenzräumen, Berlin: Lit Verlag, 17-56.

Buschmann, Nikolaus (2013): “Persönlichkeit und geschichtliche Welt. Zur praxeologischen Konzeptualisierung des Subjekts in der Geschichtswissenschaft”, in: Thomas Alkemeyer/Gunilla Budde/Dagmar Freist (eds.), Selbstbindungen. Soziale und kulturelle Praktiken der Subjektivierung, Bielefeld: transcript, 125-149.

Butler, Judith (1997): The Psychic Life of Power: Theories in Subjection, Stanford CA: Stanford University Press.

Caregari, Laure/Leboutte, René/Sauer, Arnaud/ Scuto, Denis (2012): "Histoire industrielle - Bilan \& Perspectives", in: Hémecht 64/4: Actes des 4 e Assises de l'historiographie luxembourgeoise. 
Caregari, Laure/Lorang, Antoinette (2013): "Werkswohnungsbau in der Großregion. Eine Forschungsbilanz”, in: Mutations. Mémoires et perspectives du Bassin Minier 6, 47-60.

Carlsson-Kanyama, Annika (1998): Climate Change and Dietary Choices. How Can Emissions of Greenhouse Gases from Food Consumption be Reduced?, in: Food Policy 23/3-4, 277-293.

Chambers, J. K./Trudgill, Peter (2002): Dialectology, and edition, Cambridge: University Press.

Champion, Anthony Gerard (1989): Counterurbanization: The Changing Pace and Nature of Population Deconcentration, London: Arnold.

Cloke, Paul (2011): “Urban-rural”, in: John Agnew/David Livingstone (eds.), The Sage Handbook of Geographical Knowledge, London/Thousand Oaks/New Delhi: Sage, 563-570.

Commaille, Laurent (2004): "Ein neues Bild der Arbeitersiedlungen in Lothringen”, in: Hans-Walter Herrmann/Rainer Hudemann/Eva Kell (eds.), Forschungsaufgabe Industriekultur. Die Saarregion im Vergleich, Saarbrücken: Merziger Druckerei und Verlag, 361-374.

Crenshaw, Kimberlé (1991): “Mapping the Margins: Intersectionality, Identity Politics and Violence Against Women of Color", in: Stanford Law Review 43/6, 1241-1299.

Dasen, Véronique/Späth, Thomas (2010): Children, Memory \& Family Identity in Roman Culture, Oxford: Oxford University Press.

Degele, Nina (2010): Andere Räume. Soziale Praktiken der Raumproduktion von Drag Kings und Transgender, Bielefeld: transcript.

Deppmeyer, Korana (2005): “Das Akkulturationsmodell”, in: Günther Schörner (ed.), Romanisierung - Romanisation. Theoretische Modelle und praktische Fallbeispiele, Oxford: Archaeopress, 57-63.

Dirksmeier, Peter (2009): Urbanität als Habitus. Zur Sozialgeographie städtischen Lebens auf dem Land, Bielefeld: transcript.

Dörhöfer, Kerstin (2000): “'Halböffentlicher Raum' - eine Metapher zur Auflösung (nicht nur) räumlicher Polarität”, in: Monika Imboden/Franziska Meister/Daniel Kurz (eds.), Stadt - Geschlecht - Raum. Beiträge zur Erforschung urbaner Lebensräume im 19. und 20. Jahrhundert, Zürich: Chronos, 101-118.

Düwell, Kurt (1997): “Trier und sein Umland in der Schlußphase des Zweiten Weltkriegs”, in: Kurt Düwell/Michael Matheus (eds.), Kriegsende und Neubeginn. Westdeutschland und Luxemburg zwischen 1944 und 1947 (= Geschichtliche Landeskunde: Veröffentlichungen des Instituts für Geschichtliche Landeskunde an der Universität Mainz, vol. 46), Stuttgart: Franz Steiner Verlag, 97-106.

Eberle, Ulrike/Hayn, Doris/Rehaag, Regina/Simshäuser, Ulla (2006): Ernährungswende: Eine Herausforderung für Politik, Unternehmen und Gesellschaft, München: Oekom. 
Edwards, John (2009): Language and Identity. An Introduction, Cambridge: University Press.

European Environment Agency (EEA) (2005): Household Consumption and the Environment, EEA Report 11/2005, Kopenhagen/Luxemburg: Office for Official Publications of the European Communities.

European Environment Agency (EEA) (2012): Consumption and the Environment: 2012 Update. The European Environment State and Outlook 2010, Kopenhagen: EEA.

European Commission (2010): Violence against Women and the Role of Gender Equality, Social Inclusion and Health Strategies, Luxemburg: Publications Office of the European Union.

ESPON/University of Luxembourg (2010): Metroborder. Cross-border Polycentric Metropolitan Regions. Final Report, n. p.

Fasold, Peter (1998): Bestattungssitte und kulturelle Identität. Grabanlagen und Grabbeigaben der frühen römischen Kaiserzeit in Italien und den NordwestProvinzen, Köln: Rheinland-Verlag.

Featherstone, Mike (1995): Undoing Culture: Globalization, Postmodernism and Identity, London: Sage.

Fehlen, Fernand (2011): “'Letzebourger Deutsch'. Aus der Vorgeschichte der Luxemburger Sprache (1815-1830)", in: Association luxembourgeoise des enseignants de l'histoire (ed.), Du Luxembourg à l'Europe. Hommages à Gilbert Trausch à l'occasion de son $80^{\mathrm{e}}$ anniversaire. Luxemburg: Editions Saint-Paul, 571-591.

Fleischhauer, Rob (2013): Lasauvage. Le fer des nobles, Differdange: Amis de l'Histoire.

Foucault, Michel (2000): “The Subject and Power”, in: Michel Foucault, Power, James D. Faubion (ed.), Essential Works of Foucault 1954-1984, vol. 3 (trans. Robert Hurley), New York: The New York Press, 326-348.

Foucault, Michel (2002 [1969]): The Archeology of Knowledge (trans. A. M. Sheridan Smith), London and New York: Routledge.

Freigang, Yasmine (1997): “Die Grabmäler der gallo-römischen Kultur im Moselland. Studien zur Selbstdarstellung einer Gesellschaft”, in: Jahrbuch des Römisch-Germanischen Zentralmuseums Mainz 44, 277-440.

Friedrich, Malte (2010): Urbane Klänge: Popmusik und Imagination der Stadt, Bielefeld: transcript.

Füller, Henning/Marquardt, Nadine (2009): "Gouvernementalität in der humangeographischen Diskursforschung”, in: Georg Glaszke/Annika Mattissek (eds.), Handbuch Diskurs und Raum. Theorien und Methoden für die Humangeographie sowie die sozial- und kulturwissenschaftliche Raumforschung, Bielefeld: transcript, 83-106.

George, Michele (ed.) (2005a): The Roman Family in the Empire. Rome, Italy and Beyond, Oxford: Oxford University Press. 
George, Michele (2005b): Family Imagery and Family Values in Roman Italy, in: Michele George (ed.), The Roman Family in the Empire, Oxford: Oxford University Press, 37-66.

Gergen, Kenneth (1991): The Saturated Self: Dilemmas of Identity in Contemporary Life, New York: Basic Books.

Gertenbach, Lars (2012): "Governmentality Studies. Die Regierung der Gesellschaft im Spannungsfeld von Ökonomie, Staat und Subjekt”, in: Stephan Moebius (ed.), Kultur. Von den Cultural Studies bis zu den Visual Studies. Eine Einführung, Bielefeld: transcript, 109-127.

Gilles, Peter (1999): Dialektausgleich im Lëtzebuergeschen. Zur phonetisch-phonologischen Fokussierung einer Nationalsprache (= Phonai, vol. 44), Tübingen: Niemeyer.

Gilles, Peter (2000): “Die Konstruktion einer Standardsprache. Zur Koinédebatte in der luxemburgischen Linguistik”, in: Dieter Stellmacher (ed.), Dialektologie zwischen Tradition und Neuansätzen. Beiträge der Internationalen Dialektologentagung. Göttingen, 19.-21. Oktober 1998 (= Zeitschrift für Dialektologie und Linguistik, supplement 109), Stuttgart: Franz Steiner Verlag, 200-212.

Gilles, Peter (2009): “Luxemburgisch in der Mehrsprachigkeit - Soziolinguistik und Sprachkontakt”, in: Michael Elmentaler (ed.), Deutsch und seine Nachbarn, Frankfurt a.M.: Peter Lang, 185-200.

Gilles, Peter (2010): “Sprache im Minette”, in: Mutations. Mémoires et perspectives du Bassin Minier 1, 111-123.

Gilles, Peter (2011): "Mündlichkeit und Schriftlichkeit in der luxemburgischen Sprachgemeinschaft”, in: Georg Mein/Heinz Sieburg (eds.), Medien des Wissens. Interdisziplinäre Aspekte von Medialität (= Literalität und Liminalität, vol. 4), Bielefeld: transcript, 43-64.

Goethert-Polaschek, Karin (1980): Römische Gläser im Rheinischen Landesmuseum Trier, Trier: Selbstverlag des Rheinischen Landesmuseums.

Graumann, Carl Friedrich (1983): “On Multiple Identities”, in: International Social Science Journal 35, 309-321.

Habermas, Jürgen (1990[1988]): The Philosophical Discourse of Modernity (trans. Frederick G. Lawrence), Cambridge: Polity Press.

Haffner, Alfred/von Schnurbein, Siegmar (2000): Kelten, Germanen, Römer im Mittelgebirgsraum zwischen Luxemburg und Thüringen. Akten des Internationalen Kolloquiums zum DFG-Schwerpunktprogramm "Romanisierung" in Trier vom 28. bis 30. September 1998, Bonn: Dr. Rudolf Habelt.

Harris, Richard/Larkham, Peter (eds.) (1999): Changing Suburbs: Foundation, Form and Function, London: Spon.

Harris, Richard (2006): Creeping Conformity. How Canada Became Suburban 1900-1960, Toronto: University of Toronto Press.

Harris, Richard (2010): “Meaningful Types in a World of Suburbs”, in: Research in Urban Sociology 10 (Suburbanization in Global Society), 15-47. 
Heinzelmann, Michael/Ortalli, Jacopo/Fasold, Peter/Witteyer, Marion (2001): Römischer Bestattungsbrauch und Beigabensitten in Rom, Norditalien und den Nordwestprovinzen von der späten Republik bis in die Kaiserzeit. International Colloquium, Rome 1-3 April 1998, Wiesbaden: Dr. Ludwig Reichert.

Herde, Adina (2005): Kriterien für eine nachhaltige Ernährung auf Konsumentenebene, Discussion Paper 20/05, October 2005, Berlin: Technische Universität Berlin, Zentrum Technik und Gesellschaft.

von Hesberg, Henner (2008): “The Image of the Family on Sepulchral Monuments in the Northwest Provinces”, in: Sinclair Bell/Inge Lyse Hansen (eds.), Role Models in the Roman World. Identity and Assimilation, Ann Arbor: The University of Michigan Press, 257-269.

Hesse, Markus (2010): "Suburbs: The next Slum? Explorations into the Contested Terrain of Social Construction and Political Discourse”, in: Articulo - Journal of Urban Research 3, http://articulo.revues.org/1552, accessed 20.02.2014.

Hess-Lüttich, Ernest W. B. (2004): “Die sozialsymbolische Funktion der Sprache. The Social Symbolic Function of Language”, in: Ulrich Ammon/Norbert Dittmar/Klaus J. Mattheier/Peter Trudgill (eds.), Sociolinguistics. Soziolinguistik. An International Handbook of the Science of Language and Society. 2nd completely revised and extended edition. Volume 1 (= Handbücher zur Sprach- und Kommunikationswissenschaft, vol. 3.1), Berlin/New York: de Gruyter, 491-502. Hingley, Richard (2010): "Cultural Diversity and Unity: Empire and Rome”, in: Shelley Hales/Tamar Hodos (eds.), Material Culture and Social Identities in the Ancient World, Cambridge: University Press, 54-75.

Hodos, Tamar (2010): "Local and Global Perspectives in the Study of Social and Cultural Identities", in: Shelley Hales/Tamar Hodos (eds.), Material Culture and Social Identities in the Ancient World, Cambridge: University Press, 3-31.

Hudemann, Rainer/Wittenbrock, Rolf (eds.) (1991): Stadtentwicklung im deutschfranzösisch-luxemburgischen Grenzraum (19. u. 20. Jh.) (= Veröffentlichungen der Kommission für Saarländische Landesgeschichte und Volksforschung, vol. 21), Saarbrücken: SDV.

Huebner, Sabine (2011): "Household Composition in the Ancient Mediterranean What do we really know?”, in: Beryl Rawson (ed.), A Companion to Families in the Greek and Roman Worlds, Malden/Oxford: Blackwell, 73-91.

Huskinson, Janet (2011): "Picturing the Roman Family", in: Beryl Rawson (ed.), A Companion to Families in the Greek and Roman Worlds, Malden/Oxford: Blackwell, 521-541.

Interregionale Arbeitsmarktbeobachtungsstelle (IBA) (ed.) (2013): Die Arbeitsmarktsituation in der Großregion. 8. Bericht an den Gipfel der Großregion, Saarbrücken.

Jaksche, Jutta (2005): “Ernährungspolitik - Zum Wohle des Verbrauchers” in: Karl-Michael Brunner/Gesa Schönberger (eds.), Nachhaltigkeit und Ernährung. Produktion - Handel - Konsum, New York/Frankfurt a.M.: Campus, $263-276$. 
Jameson, Fredric (1991): Postmodernism or the Cultural Logic of Late Capitalism, Durham: Duke University Press.

Kant, Immanuel (1786): Grundlegung zur Metaphysik der Sitten, Riga: Johann Friedrich Hartknoch.

Kant, Immanuel (1999): Critique of Pure Reason (trans. and eds. Paul Guyer and Allen W. Wood) (The Cambridge Edition of the Works of Immanuel Kant), Cambridge: Cambridge University Press.

Keupp, Heiner/Ahbe, Thomas/Gmür, Wolfgang/Höfer, Renate/Mitzscherlich, Beate/Kraus, Wolfgang/Straus, Florian (2006): Identitätskonstruktionen. Das Patchwork der Identitäten in der Spätmoderne, Reinbek bei Hamburg: Rowohlt.

Kieffer, Marcel (2006): “Kind der Kolonien”, in: Ville d'Esch-sur-Alzette (ed.), 100 Joer Esch. 1906-2006, Luxembourg: Editions Guy Binsfeld, 306-311.

Kirby, Andrew/Modarres, Ali (2010): “The Suburban Question: An Introduction”, in: Cities 27/2, 65-67.

Kloosterman, Robert/Musterd, Sako (2001): “The Poycentric Urban Region: Towards a Research Agenda”, in: Urban Studies 38/4, 623-633.

Knebeler, Christophe/Scuto, Denis (2010): Belval. Passé, présent et avenir d'un site luxembourgeois exceptionnel (1911-2011), Esch-sur-Alzette: Editions Le Phare.

Kockel, Valentin (1993): Porträtreliefs stadtrömischer Grabbauten. Ein Beitrag zur Geschichte und zum Verständnis des spätrepublikanisch-frühkaiserzeitlichen Privatporträts, Mainz: Verlag Philipp von Zabern.

Krause, Jens-Uwe (2003): “Antike”, in: Andreas Gestrich/Jens-Uwe Krause/Michael Mitterauer (eds.), Geschichte der Familie, Stuttgart: Alfred Kröner Verlag.

Kudera, Werner/Voß, Günter (2000): Lebensführung und Gesellschaft. Beiträge zu Konzept und Empirie alltäglicher Lebensführung, Wiesbaden: Verlag für Sozialwissenschaften.

Latour, Bruno (1993): We Have Never Been Modern (trans. Catherine Porter), Cambridge Massachusetts: Harvard University Press.

Lefèbvre, Louis (1975): “Les sculptures gallo-romaines du musée d'Arlon”, in: Bulletin trimestriel de l'Institut archéologique du Luxembourg, Arlon 7, 1-91.

Lemke, Thomas (2008): “Gouvernementalität”, in: Clemens Kammler (ed.), Foucault-Handbuch. Leben - Wirkung - Werk, Stuttgart/Weimar: Metzler, 26o263.

Lorang, Antoinette (1994): Luxemburgs Arbeiterkolonien und billige Wohnungen: 1860 - 1940. “...wo der Arbeiter sich daheimfühlt und die Schnapskneipe meiden lernt”, Luxembourg: Ministère du Logement.

Macdonald, Sharon (2013): Memorylands. Heritage and Identity in Europe Today, London: Routledge.

Mariën, Marcel Edouard (1945): Les monuments funéraires de l'Arlon romain (= Annales de l'Institut Archéologique du Luxembourg, vol. 76), Arlon: Institut Archéologique du Luxembourg. 
Marx, Karl/Engels, Friedrich (1970): The German Ideology (trans. W. Lough, C. Dutt and C. P. Magill), London: Lawrence \& Wishart Ltd.

McCarthy, James (2008): "Rural geography: Globalizing the countryside", in: Progress in Human Geography 32/1, 129-137.

Michel, Joël (1989): "Die industriellen Beziehungen im französischen Bergbau vom Ende des 19. bis in die 7oer Jahre des 20. Jahrhunderts”, in: Gerald D. Feldman/Klaus Tenfelde (eds.), Arbeiter, Unternehmer und Staat im Bergbau. Industrielle Beziehungen im internationalen Vergleich, München: Beck, 220225 .

Mitchell, Clare J. (2004): “Making Sense of Counterurbanization”, in: Journal of Rural Studies 20/1, 15-34.

Moebius, Stephan (2008): "Handlung und Praxis. Konturen einer poststrukturalistischen Praxistheorie”, in: Stephan Moebius/Andreas Reckwitz (eds.), Poststrukturalistische Sozialwissenschaften, Frankfurt a.M.: Suhrkamp, 2008, 58-74.

Nicolaides, Becky (2006): "How Hell Moved from the City to the Suburbs", in: Kevin Kruse/Thomas Sugrue (eds.), The New Suburban History, Chicago/ London: University of Chicago Press, 80-98.

Nienaber, Birte/Kriszan, Agnes (2013): “Entgrenzte Lebenswelten: Wohn- und Arbeitsmigration als Ausdruck transnationaler Lebensentwürfe im deutschluxemburgischen und deutsch-polnischen Grenzraum”, in: Raumforschung und Raumordnung 71/3, 221-232, http://link.springer.com/article/10.1007 \%2Fs13147-013-0230-2, accessed 20.02.2014.

Nietzsche, Friedrich (2009 [1885]): Digitale Kritische Gesamtausgabe (eKGWB), www.nietzschesource.org/\#eKGWB/NF-1885,38, accessed 20.02.2014.

Paasi, Anssi (2002): "Bounded Spaces in the Mobile World. Deconstructing 'Regional Identity”, in: Tijdschrift voor economische en sociale Geografie 93/2, 137-148.

Paasi, Anssi (2003): “Region and Place: Regional Identity in Question”, in: Progress in Human Geography 27/4, 475-485.

Pagliarini, Luciano/Heng, Clemens (2009): L'autre mine. La mine dite "Bei de Collaren” à Esch-sur-Alzette. Période de 1726 à 1912, Esch-sur-Alzette: Editons Schortgen.

Paluch, Didier (1997): Périurbanisation: une croissance continue. Nord-Pas-deCalais Profils, Lille: INSEE Nord-Pas-de-Calais.

Parr John B. (2004): “The polycentric urban region: a closer inspection”, in: Regional Studies 38/3, 231-240.

Pflug, Hermann (1989): Römische Porträtstelen in Oberitalien. Untersuchungen zur Chronologie, Typologie und Ikonographie, Mainz: Verlag Philipp von Zabern.

Piorr, Annette/Ravetz, Joe/Tosics, Ivan (2011): Peri-urbanisation in Europe. Towards European Policies to Sustain Urban-Rural Futures. Synthesis Report, Frederiksberg: University of Copenhagen/Forest \& Landscape. 
Pirling, Renate (1986): Römer und Franken am Niederrhein, Mainz: Verlag Philipp von Zabern.

Pratt, Geraldine (1994): “Suburbs", in: Ron Johnston/Derek Gregory/David Smith (eds.), Dictionary of Human Geography, zrd edition, Cambridge: Blackwell, 606-607.

Prykhodko, Olena (2008): "Are Mini Skirts Guilty? The Discourse on Sexual Harassment as Cultural Phenomenon in Public Spaces", in: Feministisches Kollektiv (ed.), Street Harassment. Machtprozesse und Raumproduktion, Wien: Mandelbaum Verlag, 37-54.

Quasten, Heinz (1970): Die Wirtschaftsformation der Schwerindustrie im Luxemburger Minett, Saarbrücken: Universität des Saarlandes.

Raco, Mike (2006): "Building New Subjectivities: Devolution, Regional Identities and the Re-scaling of Politics", in: Mark Tewdwr-Jones/Phil Allmendinger (eds.), Territory, Identity and Spatial Planning, London: Routledge, 320-334.

Reckinger, Rachel (2007a): “Le vin”, in: Sonja Kmec/Benoît Majerus/Michel Margue/Pit Péporté (eds.), Lieux de mémoire au Luxembourg, vol. 1: Usages du passé et construction nationale, Luxembourg: Editions Saint-Paul, 305-310. Reckinger, Rachel (2007b): "La bière”, in: Sonja Kmec/Benoît Majerus/Michel Margue/Pit Péporté (eds.) Lieux de mémoire au Luxembourg, vol. 1: Usages du passé et construction nationale, Luxembourg: Editions Saint-Paul, 311-317.

Reckinger, Rachel/Baltes-Löhr, Christel/Prüm, Agnès/Wille, Christian (2011): "Everyday Cultures and Identities", in: IPSE (ed.), Doing Identity in Luxembourg. Subjective Appropriations - Institutional Attributions - Socio-Cultural Milieus, Bielefeld: transcript, 233-290.

Reckinger, Rachel/Schulz, Christian/Wille, Christian (2011): „Identity Constructions in Luxembourg“, in: IPSE (ed.), Doing Identity in Luxembourg. Subjective Appropriations - Institutional Attributions - Socio-Cultural Milieus, Bielefeld: transcript, 291-294.

Reckinger, Rachel (2011): "De la terre natale symbolique au terroir sensoriel. Usage politique et normativité didactique du discours sur l'origine des vins", in: Serge Wolikow/Olivier Jacquet/Christophe Lucand (eds.), De Jules Guyot à Robert Parker: 150 ans de construction des territoires du vin, Dijon: Editions Universitaires de Dijon, 259-268.

Reckinger, Rachel (2012a): Parler vin. Entre normes et appropriations, Tours/ Rennes: Presses Universitaires François Rabelais/Presses Universitaires de Rennes.

Reckinger, Rachel (2012b): "Produits culinaires régionaux", in: Sonja Kmec/ Pit Péporté (eds.): Lieux de mémoire au Luxembourg, vol. 2: Jeux d'échelles, Luxembourg: Editions Saint-Paul, 181-186.

Reckinger, Rachel (2013): Der Gouvernementalitätsbegriff. Eine Perspektive zur Untersuchung von Raum- und Identitätskonstruktionen (= IDENT2-Working Papers 4), Luxemburg, http://wwwen.uni.lu/content/download/62474/ 745288/file/IDENT2_Working-Paper_04-2013.pdf, accessed 23.12.2013. 
Reckwitz, Andreas (2003): "Grundelemente einer Theorie sozialer Praktiken. Eine sozialtheoretische Perspektive”, in: Zeitschrift für Soziologie 32/4, 282301.

Reckwitz, Andreas (2004): “Die Entwicklung des Vokabulars der Handlungstheorien: Von den zweck- und normorientierten Modellen zu den Kultur- und Praxistheorien", in: Manfred Gabriel (ed.), Paradigmen der akteurszentrierten Soziologie, Wiesbaden: Verlag für Sozialwissenschaften, 303-328.

Reckwitz, Andreas (2006): Das hybride Subjekt. Eine Theorie der Subjektkulturen von der bürgerlichen Moderne zur Postmoderne, Weilerswist: Velbrück Wissenschaft.

Reckwitz, Andreas (2008a): Subjekt, Bielefeld: transcript.

Reckwitz, Andreas (2008b): “Subjekt/Identität”, in: Stephan Moebius/Andreas Reckwitz (ed.), Poststrukturalistische Sozialwissenschaften, Frankfurt a.M.: Suhrkamp, 75-92.

Reckwitz, Andreas (2009): “Praktiken der Reflexivität: Eine kulturtheoretische Perspektive auf hochmodernes Handeln”, in: Fritz Böhle/Margit Weihrich (eds.), Handeln unter Unsicherheit, Wiesbaden: Verlag für Sozialwissenschaften, $169-182$.

Reckwitz, Andreas (2010): “Auf dem Weg zu einer kultursoziologischen Analytik zwischen Praxeologie und Poststrukturalismus", in: Monika Wohlrab-Sahr (ed.), Kultursoziologie. Paradigmen - Methoden - Fragestellungen, Wiesbaden: Verlag für Sozialwissenschaften, 179-205.

Reddeker, Sebastian (2011): “Collective Symbols and (New) Identity Options in Luxembourg's Advertising”, in: IPSE (ed.), Doing Identity in Luxembourg. Subjective Appropriations - Institutional Attributions - Socio-Cultural Milieus, Bielefeld: transcript, 190-202.

Reuter, Julia (2008): “Globalisierung: Phänomen - Debatte - Rhetorik”, in: Stephan Moebius/Andreas Reckwitz (eds.): Poststrukturalistische Sozialwissenschaften, Frankfurt a.M.: Suhrkamp, 263-276.

Riehl, Claudia Maria (1999): “Grenzen und Sprachgrenzen”, in: Monika Fludernik/Hans-Joachim Gehrke (eds.), Grenzgänger zwischen Kulturen (= Identitäten und Alteritäten, vol. 1), Würzburg: Ergon, 41-56.

Rose, Hannelore (2007): "Privatheit als öffentlicher Wert - Zur Bedeutung der Familie auf Grabmonumenten der Gallia Belgica”, in: Elisabeth Walde/Barbara Kainrath (eds.), Die Selbstdarstellung der römischen Gesellschaft in den Provinzen im Spiegel der Steindenkmäler, Innsbruck: Innsbruck University Press, 207-224.

Rothe, Ursula (2009): Dress and Cultural Identity in the Rhine-Moselle Region of the Roman Empire, Oxford: Archaeopress.

Ruhne, Renate (2011): Raum Macht Geschlecht. Zur Soziologie eines Wirkungsgefüges am Beispiel von (Un)Sicherheiten im öffentlichen Raum, Wiesbaden: Verlag für Sozialwissenschaften. 
Sabrow, Martin (2006): “Die NS-Vergangenheit in der geteilten deutschen Geschichtskultur”, in: Christoph Kleßmann/Peter Lautzas (eds.): Teilung und Integration. Die doppelte deutsche Nachkriegsgeschichte als wissenschaftliches und didaktisches Problem (= Reihe Politik und Bildung, vol. 41), Schwalbach/Ts.: Wochenschau, 132-151.

Schmid, Christian/Brenner, Neil (2011): "Planetary Urbanisation”, in: Matthew Gandy (ed.), Urban Constellations, Berlin: Jovis, 10-13.

Schmidt, Robert (2012): Soziologie der Praktiken. Konzeptionelle Studien und empirische Analysen, Frankfurt a.M.: Suhrkamp.

Schmitz, Walter (2007): “Die europäische Stadt: Teil unseres kulturellen Erbes”, in: Erich Greipl/Stefan Müller (eds.), Zukunft der Innenstadt. Herausforderungen für ein erfolgreiches Stadtmarketing, Wiesbaden: Gabler Verlag, 33-45.

Schnuer, Gregor/Boesen, Elisabeth/Wille, Christian (2013): “We, You, the Others. Constructions of Difference and Identity in the Greater Region", lecture at the 12th International Conference "European Culture", Universitat Internacional de Catalunya, Barcelona.

Scholz, Markus (2012): Grabbauten des 1.-3. Jahrhunderts in den nördlichen Grenzprovinzen des Römischen Reiches, vol. 1, Mainz: Verlag des RömischGermanischen Zentralmuseums.

Schörner, Günther (2005): “Einführung”, in: Günther Schörner (ed.), Romanisierung - Romanisation. Theoretische Modelle und praktische Fallbeispiele, Oxford: Archaeopress, V-XVI.

Schrott, Karin (2005): Das normative Korsett. Reglementierungen für Frauen in Gesellschaft und Öffentlichkeit in der deutschsprachigen Anstands- und Benimmliteratur zwischen 1871 und 1914, Würzburg: Königshausen \& Neumann.

Sedlacko, Michal/Reisch, Lucia/Scholl, Gerd (2013): “Sustainable Food Consumption. When Evidence-Based Policy-Making Meets Policy-Minded Research. Introduction to the Special Issue”, in: Sustainability: Science, Practice \& Policy 9/2, 1-6, http://sspp.proquest.com, accessed 20.02.2014.

Setzwein, Monika (2006): “Frauenessen - Männeressen? Doing Gender und Essverhalten”, in: Petra Kolip/Thomas Altegeld (eds.), Geschlechtergerechte Gesundheitsförderung und Prävention. Theoretische Grundlagen und Modelle guter Praxis, Weinheim/München: Juventa Verlag, 41-6o.

Sieburg, Heinz (2013): “Die Stellung der deutschen Sprache in Luxemburg. Geschichte und Gegenwart”, in: Heinz Sieburg (ed.), Vielfalt der Sprachen - Varianz der Perspektiven. Zur Geschichte und Gegenwart der Luxemburger Mehrsprachigkeit (= Interkulturalität. Studien zu Sprache, Literatur und Gesellschaft, vol. 3), Bielefeld: transcript, 81-106.

Sonntag, Monika (2013): Grenzen überwinden durch Kultur? Identitätskonstruktionen von Kulturakteuren in europäischen Grenzregionen (= LuxemburgStudien/Etudes luxembourgeoises, vol. 3), Frankfurt a.M.: Peter Lang. 
STATEC (Statistics Portal Grand-Duchy of Luxembourg) (2012): Luxemburg in Zahlen, Luxemburg: STATEC.

STATEC (Statistics Portal Grand-Duchy of Luxembourg) (2013): Luxemburg in Zahlen. Edition 2013, Luxemburg: STATEC.

Strüver, Anke (2010): “KörperMachtRaum und RaumMachtKörper: Bedeutungsverflechtungen von Körpern und Räumen”, in: Sybille Bauriedl/Michaela Schier/Anke Strüver (eds.), Geschlechterverhältnisse, Raumstrukturen, Ortsbeziehungen. Erkundung von Vielfalt und Differenz im spatial turn, Münster: Westfälisches Dampfboot, 217-237.

Sustainable Development Commission (SDC) (2009): Setting the Table: Advice to Government on Priority Elements of Sustainable Diets, London: Sustainable Development Commission.

Tenfelde, Klaus (1991): “Ende der Arbeiterkultur: Das Echo auf eine These”, in: Wolfgang Kabuschka/Gottfried Korff/Bernd Jürgen Warneken (eds.), Arbeiterkultur seit 1945. Ende oder Veränderung?, Tübingen: Tübinger Vereinigung für Volkskunde, 19-30.

Trausch, Gilbert (2000): L'ARBED dans la société luxembourgeoise, Luxemburg: V. Bruck.

Vaughan, Laura/Griffiths, Sam/Haklay, Muki/Jones, Catherine Emma (2009): "Do the Suburbs Exist? Discovering Complexity and Specificity in Suburban Built Form”, in: Transactions of the Institute of British Geographers 34, 475488.

Vicenzotti, Vera (2011): Der “Zwischenstadt”-Diskurs. Eine Analyse zwischen Wildnis, Kulturlandschaft und Stadt, Bielefeld: transcript.

Walde, Elisabeth/Kainrath, Barbara (eds.) (2007): Die Selbstdarstellung der römischen Gesellschaft in den Provinzen im Spiegel der Steindenkmäler. IX. internationales Kolloquium über Probleme des provinzialrömischen Kunstschaffens, Innsbruck: Innsbruck University Press.

Wastl-Walter, Doris (2010): Gender Geographien. Geschlecht und Raum als soziale Konstruktionen, Stuttgart: Franz Steiner Verlag.

Weichhart, Peter (1990): Raumbezogene Identität. Bausteine zu einer Theorie räumlich-sozialer Kognition und Identifikation, Stuttgart: Franz Steiner Verlag.

Weimann, Britta (2013): “Überlegungen zur Entwicklung der Mündlichkeit und Schriftlichkeit in Luxemburg”, in: Heinz Sieburg (ed.), Vielfalt der Sprachen - Varianz der Perspektiven. Zur Geschichte und Gegenwart der Luxemburger Mehrsprachigkeit (= Interkulturalität. Studien zu Sprache, Literatur und Gesellschaft, vol. 3), Bielefeld: transcript, 251-262.

Welzer, Harald/Moller, Sabine/Tschuggnall, Karoline (2002): “Opa war kein Nazi.” Nationalsozialismus und Holocaust im Familiengedächtnis (= Die Zeit des Nationalsozialismus, vol. 15515), Frankfurt a.M.: Fischer.

West, Candace/Zimmerman, Don H. (1987): “Doing Gender”, in: Gender \& Society. Official Publication of Sociologists for Women in Society 1, 125-151. 
von Massow, Wilhelm (1940): "Bronzestatuette einer Göttin aus Belginum", in: Trierer Zeitschrift 15, 28-34.

Wille, Christian (2009): "Eine namenlose Region", in: Forum 288, 30-31.

Wille, Christian (2010): “'Doing Grande Région.' Espace entre transgression et construction à l'exemple du frontalier", in: Gaëlle Crenn/Jean-Luc Deshayes (eds.), La construction des territoires en Europe. Luxembourg et Grande Région: Avis de recherches, Nancy: Presses universitaires de Nancy, 81-93.

Wille, Christian (2012): Grenzgänger und Räume der Grenze. Raumkonstruktionen in der Großregion SaarLorLux (= Luxemburg-Studien/Etudes luxembourgeoises, vol. 1), Frankfurt a.M.: Peter Lang.

Wineburg, Sam (2001): "Sinn machen: Wie Erinnerung zwischen den Generationen gebildet wird”, in: Harald Welzer (ed.), Das soziale Gedächtnis. Geschichte, Erinnerung, Tradierung, Hamburg: Hamburger Edition, 179-204.

Woods, Michael (2007): "Engaging the Global Countryside: Globalization, Hybridity and the Reconstitution of Rural Place", in: Progress in Human Geography 31/4, 485-507.

Wucherpfennig, Claudia (2010): "Geschlechterkonstruktionen und öffentlicher Raum”, in: Sybille Bauriedl/Michaela Schier/Anke Strüver (eds.), Geschlechterverhältnisse, Raumstrukturen, Ortsbeziehungen. Erkundung von Vielfalt und Differenz im spatial turn, Münster: Westfälisches Dampfboot, 48-74.

Würzbach, Natascha (2014): "Raumdarstellung”, in: Vera Nünning/Ansgar Nünning (eds.): Erzähltextanalyse und Gender studies, Stuttgart: JM Metzler, 49-71.

Young, Doug/Wood, Patricia/Keil, Roger (2011): In-Between Infrastructure: Urban Connectivity in an Age of Vulnerability, Toronto: Praxis (e)Press.

Zanker, Paul (1975): "Grabreliefs römischer Freigelassener", in: Jahrbuch des Deutschen Archäologischen Instituts 90, 267-315. 
Christian Wille, Rachel Reckinger, Sonja Kmec, Markus Hesse (eds.)

\section{SPACES AND}

IDENTITIES IN

\section{BORDER REGIONS}

Politics - Media - Subjects

[transcript] Culture and Social Practice 
Christian Wille, Rachel Reckinger, Sonja Kmec, Markus Hesse (eds.) Spaces and Identities in Border Regions

Culture and Social Practice 
E-Book von Christian Wille, christian.wille@uni.lu

27.01.2016 17:18

Copyright 2016, transcript Verlag, Bielefeld 
Christian Wille, Rachel Reckinger, Sonja Kmec, Markus Hesse (eds.)

\section{Spaces and Identities in Border Regions}

Politics - Media - Subjects

\section{[transcript]}




\section{Bibliographic information published by the Deutsche Nationalbibliothek}

The Deutsche Nationalbibliothek lists this publication in the Deutsche Nationalbibliografie; detailed bibliographic data are available in the Internet at http://dnb.d-nb.de

\section{(๔) 2015 transcript Verlag, Bielefeld}

All rights reserved. No part of this book may be reprinted or reproduced or utilized in any form or by any electronic, mechanical, or other means, now known or hereafter invented, including photocopying and recording, or in any information storage or retrieval system, without permission in writing from the publisher.

Cover layout: Kordula Röckenhaus, Bielefeld

Cover illustration: misterQM / photocase.de

English translation: Matthias Müller, müller translations (in collaboration with Jigme Balasidis)

Typeset by Mark-Sebastian Schneider, Bielefeld

Printed in Germany

Print-ISBN 978-3-8376-2650-6

PDF-ISBN 978-3-8394-2650-0 